\title{
Determinates of Budget Deficit in Selected East and West African Countries: A Dynamic Panel Data Approach
}

\author{
Wondimhunegn Atilaw Woledetensaye \\ Lecturer, Department of Economics, in Mizan Tepi University, Ethiopia
}

\begin{abstract}
Budget deficits imitate rank of monetary health in which public outflow exceed public inflow. In this study the determinates of budget deficit analyzed in two regions east and west African cross countries from the year of 2000 to 2017 using a dynamic panel data approach. The data is obtained from WDI, IMF database and annual reports of these institutions. The study employed least square dummy variable fixed effect estimations technique of the model and It also investigate interaction variable of debt regressions result to know whether the source of debt in the regions of countries are same or not. The result reveals that higher number of unemployment, broad money supply and high amount of total population growth are associated with a significant effect on budget deficit. While real gross domestic product, debt and inflations rate are showed insignificant effect on budget deficit in the analysis of the regions. The study also including time invariant variable in the estimation result that is country dummy in the study implied that, as comparing to Ethiopia the amount of budget deficit in Tanzania, Senegal and Cote Divore are higher amount of public deficit implied by country dummy analysis of this study. The study indicates as policy implications reducing higher level of unemployment, broad money supply and populations' growth rate are technically reducing budget deficit of the regions and knowing the optimum amount of budget that raised by the policy maker to the economy is crucial to the regions. Finally on the basis of this study, it makes a number of recommendations to reduce budget deficits in the regions.
\end{abstract}

Keywords:budget, determinates, panel, fixed, LSDV, east and West Africa

DOI: $10.7176 / \mathrm{JESD} / 13-3-01$

Publication date: February $28^{\text {th }} 2022$

\section{Introduction}

Macroeconomic solidity of a country is highly reliant on government budget strategy. But reducing budget deficit is a complex process being dependent on a large number of economic interactions, including external factors. Discussing the budgetary process to identify the factors that are contributory or detrimental to budget deficit, in line with economic theories and international empirical observations is a crucial importance (ECA, 2007).

The budget deficits of Africa increasing in 2008 and 2009, as their revenue contracted more than their expenditure. Deficits increase from $0.3 \%$ share of GDP in 2008 to $1.2 \%$ share of GDP in 2009 . The developed economies were remaining relatively stable, with a deficit of $0.3 \%$ in 2010 and $0.1 \%$ in 2011 (IMF, 2010a). These forecasts, however, conceal differences among these countries (Economic Report of Africa, 2010).

Especially East Africa's fiscal deficit is widened somewhat from 4.0 to $4.6 \%$ in 2016, reflecting expansionary fiscal policies, mainly in Ethiopia (notably spending on infrastructure), Kenya (a new railway line, sharply increased government salaries and transfers to new country) and Uganda (hydropower projects) (Economic Commission for Africa, 2017). The fiscal deficit widened in West Africa in 2016, from 1.8 to $2.8 \%$ of GDP, largely reflecting in Nigeria; spending on security, Cote Divore ; Spending on rising minimum wage rate, Security and public investment especially on building of infrastructure: Ghana; spending on politics especially election related expenses and increasing wage on public sector (Ibid).In Africa the issues souring budget deficit are not certainly new, but the economic development of past decayed has lead to renewed interest in the fiscal budgets (Adriana , 2005).Improving fiscal performance by reducing budget deficits has for long been at the heart of many governments due to the negative consequences. Such as, economic disability and high inflation (Dissanayake, 2016).

Ali (2003) traditional views of budget deficit taken by most economists argued that when government runs budget deficit and issues of deficits, it reduces national saving which reduce net investment increase foreign debt. This view concludes that, Government debt place burden on feature generation. While Recardian views of government budget merely represent a substitution of feature taxes for current taxes budget of the country may affect nation role in the world economy (Mankiw, 2007; Fareeha and Ihtsham, 2017).

To maintain macroeconomic stability in a country, economic policy makers need to consider current economic issues, historical trends as well as potential threats and benefits in future (Javid A at el., 2011). Budgetary process is a multi-dimensional process with many economic variables affecting the outcome. One issue of relevance linked to growth strategy is whether the rapid development of one or two sectors would be sufficient to ensure budgetary balance (Morra, 2014).

African especially the sub Saharan countries budget deficit is highly increase from time to time due to government intervention on social, political, economic affair and the climatic difficulty as well as poor tax 
collection system of the countries (Christian et al.,2016).

Attaining a sound macroeconomic balance has the primary or priority objectives both on industrial and developing countries economic in the measurement of success by public sector (Gongera et al., 2013). The extent of government deficits and debt has been one of the most debated issues in economics in recent years (Attiya et al., 2010).

Most of the world countries are; especially Africa has long economic history of characterized by macroeconomic imbalance (Robert, 2017). But now they tried to build strong economic growth especially from the outbreak of global finical and economic crisis starting onward GDP growth on average in Africa is raising from $2.3 \%$ in 2009 to $4.7 \%$ in 2010 (ECA ,2011). It is perceived a larger deficit significant as a result of more expansionary fiscal policy especially subsidy on the Agriculture (\% of GDP), Industry (\% of GDP), Manufacturing (\% of GDP) and Services (\% of GDP) (ECA, 2017). On average east and west Africa government expenditure on these sector are from 1990-2012 proportionally expend to overcome the economic growth of the country $24.312 \%$, $9.908 \%, 5.878 \%, 24.13 \%$ and $22.237 \%, 18.372 \%, 5.064 \%, 31.807 \%$ as share of GDP would be expend by the public sector respectively in the regions which having the great contribution for the out coming of deficit (Ibid). But it was no always true because during recession as gap falls government most important source of revenues such as income tax, corporate tax and payroll tax all are shrink because firm's and people pay lower tax than when they earn less (Assefa,2015)

Depending on this; Macroeconomic stability of a country is highly dependent on government budget strategies (www.freedomdebtrelief.com). But reducing budget deficit is a complex process being dependent on a large number of economic interactions, including external factors. To maintain macroeconomic stability in a country, economic policy makers need to consider current economic issues, historical trends as well as potential threats and benefits in future. The budgetary process has a multi-dimensional process with many economic variables affecting the outcome (Dissanayake, 2016).

But determinants and role of budget deficits have always been debated issues by elite groups, however yielding assorted conclusions. Among those who contributed to the role playing by budget deficits is (Hobbes, 1651) who credited the government as the solitary provider of a decent life. Latter on supported by (Keynes, 1936) his argument is that without government economy would be fail. (Kustepeli, 2005) supported the views of Hobbes and Keynes with the idea of large government is good for Economic performance. Another economist who believes fiscal policy is the instrument no need of government interventions to bring stable economic balance on the countries supported by (Musgrave ,1959) argued that government always use as frame work of fiscal policy to improve the life and welfare of the society. Contrary to these, economists ranging from classical to those holding the public choice view argued against the use of budget deficits to improve economic performance. In particular, (Smith, 1776; Ricardo, 1817; and Pigou, 1912) suggested that instabilities in the economy are a result of government interferences (Genius et al., 2013).

\section{Literature Review}

\subsection{Determinant of Budget Deficit in low income countries}

There can be socio-economic development differences, political and structural factors beyond the belief of policy practitioners about the role of government in economic activities that can explain the reason why government run deficits. Budget deficits may occur as a result of increasing government activities in the economy, development theorizing problems related to the structure of the economy and political pressures to spend more than what government collect as revenue (Mika and Guido, 2004). The size of government in the economy is also an important determinant which may be included in the structural determinants of budget deficits. (Jim and Chairman, 1998) "It is a fact that no society throughout history has ever obtained a high level of economic affluence without a government". (Irma, 1999) There is no economic environments that urgently change economy even if some phase of WWII. This change has profound implications for the way the role of government has been viewed by development practitioner and their adverse in international organizations". Early works tried to identify and explained why government innervations increase over time. The earliest explanation of this kind is the wager's law. The law states that there is an increasing trend of government expenditure over time. Wagner stated that based on historical factors in Germany: There is a functional relationship between the growth of public expenditure and the growth of the economy. Wagner did not clearly refer the growth of the ratio of government expenditure to GDP or the absolute size (Dissanayake, 2016).

Budget deficit may also accrue due to inflation. But, the direct link of the case can be problematic. Inverted causation can be reputable for example monetization of discrepancy may verify to be inflationary. On the other hand, in economies where there is inflation there was pressure for running budget deficits. This was because, taxes collection exhibits collection lags that when there was inflation the real balance of tax revenue would decrease at the collection. An alternative approach to the explanation of budget deficit is the examination of structural factors. They cannot change them in the short-term. As summarized by Tasew, (2011) structural factors to budget deficit in LDCs: - Level of economic development, Growth in government revenue, Instability of government revenue, 
Extent of government participation in the economy and Size of government.

\section{Research methodology and data}

\subsection{Econometrics Model Specification and Estimation Issues}

It starts with simple model determinations characterize a variable's behavior in a Panel dataset.

$\gamma_{i t}=\beta_{i}+\beta_{2} x_{i t}+\varepsilon_{i t}$

Where $\boldsymbol{\gamma}$ is dependent variable, $\boldsymbol{x}$ is Explanatory variables and $\boldsymbol{\varepsilon}$ is the error term. While the subscripts $\boldsymbol{i}$ is the cross-sectional unit of analyses, individual country, $\boldsymbol{i}=\mathbf{1} \ldots \ldots . \boldsymbol{N}$ and $\boldsymbol{t}$ is the time period, $\boldsymbol{t}=\ldots \mathbf{1}, \mathrm{T}$ stands for unit, and period of time respectively.

The assumption about the intercept and the slope coefficients we can have different fixed effect models. In the fixed-effects model, we treat as a group-specific constant term $\left(\boldsymbol{\beta}_{\boldsymbol{i}}\right)$ to be estimated with the other parameters. It can be either time or unit constant.

When the intercept is fixed over the individual unit but not on time, $\boldsymbol{N}-\mathbf{1}$ individual dummy variable is included and the model become;

$\gamma_{i t}=\alpha_{1}+\alpha_{2} D_{2 i}+\beta_{2} x_{2 t i}+\ldots \ldots \ldots+\alpha_{N} D_{i t}+\beta_{N} x_{3 i t}+\varepsilon_{i t}$

There are no significant temporal effects; there are significant differences among unit of analysis in this type of model. When the intercept is fixed over the time but not on the individual unit, we could account for the time effect over the $\boldsymbol{t}$ years with $\boldsymbol{t}-\mathbf{1}$ time dummy variables on the right-hand side of the equation. The model become;

$\gamma_{i t}=\mu_{1}+\mu_{2} D_{2 T}+\ldots \ldots \ldots N_{T} D_{T T}+\beta_{2} x_{2 i}+\varepsilon_{i t}$

[3c]

Equation (3a) and (3c) the model would have no significant country differences but might have autocorrelation owing to time lagged temporal effects.

If the cross-section is sampled from a larger population so that exhaustiveness remains, then it may be more appropriate to view the individual- specific effects in the sample as randomly distributed effects across the full cross-section of agents. Now we can simply construct the random effect model from equation (3a) simply by assuming the intercept term is random with mean value $\boldsymbol{\beta} \boldsymbol{i}$. Its value for individual $\boldsymbol{i}$ can be expressed as

$\beta_{i}=\beta_{i}+v_{i} \ldots \ldots \ldots \ldots i=1 \ldots \ldots \ldots N \quad[3 \boldsymbol{d}]$ Substituting equation (3d) in to equation (3a); the simplest panel data model gives random panel data model which looks;

$\gamma_{i t}=\beta_{i}+\beta_{2} x_{i t}+v_{i}+\varepsilon_{i t}$

$\boldsymbol{v}_{\boldsymbol{i}}$ Is Cross sectional specific error term individual country which indicates the deviation from the constant of the cross-sectional unit. It is constant over time while, the idiosyncratic error is specific to a particular observation. It must be uncorrelated with the errors of the variables (Greene, 2003). The individual component may be in turn either independent of the regressors or correlated (Croissant and Millo, 2008). It doesn't show and capture dynamic relationship, while most macro variables and economic relations are dynamic in their nature. Budget deficit also, has a dynamic nature in which current level has likely been affected by the previous period(s). Since, it changes very slowly (Anyanwu, 2016).To capture this characteristic, true state dependency, it is better to use Lagged Dependent Variables (LDV) models (Brüderl ,2015).It can be created by introducing the lagged dependent variables to either fixed or random effects models. Judson and Owen, (2006) forming dynamic panel model on the fixed effects model is more appropriate than a random effects model for many macro datasets because of two reasons. One, if the individual outcome represent lost variables, it is highly possible that these country definite individuality are interrelated with the other regressors. Two, it is also fairly likely that a typical macro panel was contain most of the countries of interest and, thus, would be fewer likely to be a random sample from a large amount of universe. Finally dummy incorporations of random effect model were impossible. Because of these reasons our dynamic panel models was formed on the fixed effect model and it looks;-

$\gamma_{i t}=\beta_{i}+\beta_{1} \gamma_{i t-1}+\beta_{2} x_{i t}+\varepsilon_{i t}$

Where $\gamma_{i t}$ is dependent variable of individual country $\boldsymbol{i}$ at a period $\boldsymbol{t}$ and lagged dependant variable of individual country $\boldsymbol{i}$ at a period $\boldsymbol{t}-\mathbf{1}$. While, $\boldsymbol{x}_{\boldsymbol{i}}$ is other Explanatory variables and $\boldsymbol{\varepsilon}_{\boldsymbol{i}}$ is the error term. In our case the variable $\gamma_{i t}$ and $\gamma_{i t-1}$ are determinate of budget deficit across a region measured by Primary budget balance $\left(G B^{p}\right)$ : of individual country $\boldsymbol{i}$ at a period $\boldsymbol{t}$ and $\boldsymbol{t}-\mathbf{1}$ respectively. $\boldsymbol{x}_{\boldsymbol{i}}$ is other socio economic factors which are expected to have effect on determinate of budget deficit of individual country $\boldsymbol{i}$ at a period $\boldsymbol{t}$. Now we can construct the aggregate and disaggregate of macroeconomic variable that affect the budget deficit of econometrics model respectively including the above econometrics issues as a reference.

$\beta D_{t}=f\left(R G D P_{t}, U N E_{t}, M 2_{t}, I N F_{t}, P O P_{t}, D E T_{t}\right)$

Therefore the linear equation of this model is

$$
\begin{aligned}
& \beta D_{i t}=\beta_{0}+\beta_{1} R G D P_{i t}+\beta_{2} U N E_{i t}+\beta_{3} I N F_{i t}+\beta_{4} P O P_{i t}+\beta_{5} D E T_{i t}+\beta_{6} M 2_{i t}+ \\
& +\varepsilon_{i t}
\end{aligned}
$$

Where:

$\beta D_{i t}=$ is detrminate of budget deficit with country $i$ at period $t$ measured by the Primary budget balance. 
$R G D P_{i t}=i s$ Gross Domestic Product of country $i$ at a period $t$ which is a measure for economic growth adjusted for changes in the value of money inflation.

$U N E_{i t}=i$ s total amount of unemployment country $i$ at period $t$ based on the strict

definition unemployment rate (ILO).

$I N F_{i t}=$ is the annual rate of inflation country $i$ experienced at a period $t$.

$P O P_{i t}=i$ Population growth (annual \%) country $i$ at period $t$.

$D E T_{i t}=i s$ the national debt is the total amount of money payable by the government

of country $i$ at period $t$.

$M 2_{i t}=i$ s amount money supply(M2)of country $i$ at perid $t$.

Bo = common (intrcpet) constant of the cross country

$\beta^{s}=$ cofficent of explanatory variables

$\varepsilon_{i t}=$ error trms of the country $i$ at period $t$.

$t=$ time period of crossection country.

Absolute value both the right and left hand side to make the positive values of estimation $\left|\beta D_{i t}\right|=\mid \beta_{0}+\beta_{1} R G D P_{i t}+\beta_{2} U N E_{i t}+\beta_{3} I N F_{i t}+\beta_{4} P O P_{i t}+\beta_{5} D E T_{i t}+\beta_{6} M_{2 i t}+$ $\varepsilon_{i t} \mid \quad[4 a]$

Genius et al., (2013) employs in order to avoid any form of misconception of empirical results, a description of all variables that appear in the estimated equation is provides. All the explained and explanatory variables are converted to logarithms so as to remove trends and variability of the data nature. The model (in equation 4a) thus assumes the form as follows in (equation $4 \mathrm{~b}$ ).

$$
\underset{\varepsilon_{i t}}{L \beta D_{i t}}=L \beta_{0}+\beta_{1} L R G D P_{i t}+\beta_{2} L U N E_{i t}+\beta_{3} L I N F_{i t}+\beta_{4} L P O P_{i t}+\beta_{5} L D E T_{i t}+\beta_{6} L M 2_{i t}+
$$

\section{Result and Discussions}

\subsection{Econometrics result and its Discussions.}

\subsubsection{Interpretations of fixed effect least square dummy variable (LSDV) and interaction variable of debt} in the models.

The research run both cross and time series, panel data technique are applied to estimate the regression equations. The techniques make it possible to take into account country-specific factors which show very little or no variations over time. Speaking the model explaining in the fixed LSDV is $35.64 \%$ with adjusted $\mathrm{R}^{2}$ value of $27.8 \%$ when budget deficit takes its current value of the determinates. The small $\mathrm{R}^{2}$ may signify the loss of the degree of freedom $(K+N)$ in using panel data technique of estimations. Due to the reasoned of using time invariant dummy variable in this study to show the structure of budget deficit across countries. Moreover it may also indicate that some other variables, not incorporated in the model and /or the unobserved heterogeneity terms, have significant role in explain budget deficit in the regions because as explained on the introduction this study concerns on the economic aspects of analysis which clue for further investigations. The following table presented the alternative result from a fixed effect regression for the model built in chapter three (equ.4b). Model-1 show when budget deficit takes its cotemporaneous value of result when the fixed effect model capture by nature the variable of time invariant variables but having significant effect on budget deficit across countries. The result is shown in Appendix (Appendix I), the prob $>\mathrm{F}$ is $0.05(0.0011)$, So we reject the null hypothesis that the coefficients for all country dummy are jointly are not equal to zero, therefore country dummy fixed effect are needed to be shown in the cause that why this study used alternative LSDV model (Table 4.1. Model 2)beyond fixed effect model to capture the coefficient of time invariant variables.

Rationality to used LSDV model in this study is, it is one strategy among different estimations method of fixed effect model in panel data analysis. These strategies of course produce the identical parameter estimates of regressors. The between estimations fits a model using individual dependent and independent variable without dummies. LSDV with a dummy dropped out of a set of dummies widely used because it is relatively easy to estimates and interpreted substantively. This LSDV estimation technique of fixed effect model, however problematic when there are many individual groups in panel. If $T$ is fixed and $n \quad \infty$ ( $n$ is number of county and $T$ is the number of time periods), parameter estimates are consistent but the coefficient of individual effect, $a+u i$, are not (Baltgi, 2007). In this short panel, LSDV include large number dummy variables: the number of prompters to be estimated increase (incidental parameter problems): Therefore, LSDV loss n degree of freedom but return less coefficient estimators. Under this circumstance, LSDV is thus for anther strategy, the within effect estimations (Hun Myoung, 2011). 
Table 4.1: A dynamic panel data analysis of fixed effect model strategy and interaction variable of debt estimation result of across countries $(L n B D)$.

Dependent variable is log of budget deficit.

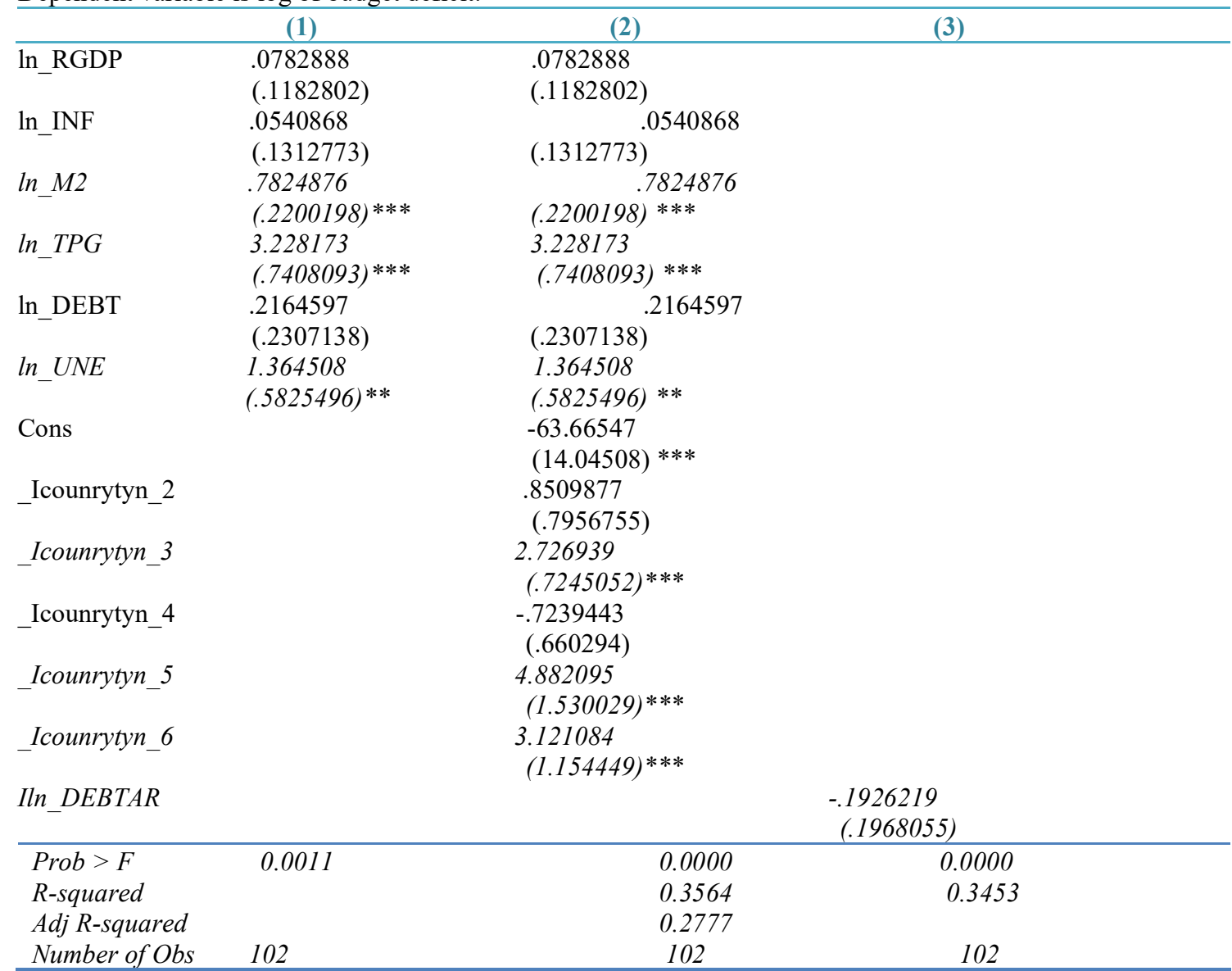

Source: Own competitions Based on Available Data (Stata SE/14.0)

Note: $1 . \quad * * *, * *$ and $*$ show significant level at $1 \%, 5 \%$ and $10 \%$ significance, respectively.

2. (1), (2) and (3) show that fixed effect, LSDV and interaction variable of the model of debt on above table respectively.

3. Icounrytyn_2, 3, 4, 5 and $6=$ is shown Country name id number two (i.e.) for Kenya, Tanzania, Nigeria, Senegal and Cote Divore respectively including Ethiopia dropping dummy by the soft ware.

4. Iln DEBTAR = interaction variable of log debt with the continues dummy variables of across countries to answer the questions of whether the source of debt has the same or not?

This sections represent the result of the empirical determinates of budget deficits in econometrics model using a panel data of six East and West African countries from the year of 2000 to 2017.(Table 4.1)Show the estimation result of fixed effect LSDV model and interaction variable of debt regression result in the natural logarithms determinate of budget deficit in the regions. In three of the regression result the dependent variable is logarithm of budget deficit. The regressors are variable used in the simple Keynesian open economy model (Salman, 2003).In this model, as the study is concerned with a dynamic panel model, the country dummy also used as explanatory variables to show how budget deficit is vary across countries in Table: 4.1(2)

The significance level of the regressions explanatory variables statistically significant logarithms of broad money supply, total population growth with expected positive sign except and total unemployment rate which would be negative. This implies that most of the public expenditure of these macroeconomic variables plays a great role to the outbreak of public deficit to improving socio economic conditions of the society of the regions. While as can be seen from the table when we treat real gross domestic product, inflation and debt in three of the regression result all are insignificant. Even if when incorporated logarithm functions all of the regressions coefficients of the variable are insignificant effect on budget deficit in the regions. Using lag lengths may be solve this problem but followed by the loss of degree of freedom since it use time invariant country dummy to the study. The possible reasons of these insignificant variables are macroeconomic insatiability of policy change of economic 
agents (Natalia, 2016). As we remember in methodology the preliminary explanations of theoretical model specifications of budget deficit; public expenditure is the function of economic growth but her is the coefficient of rgdp is statistically insignificant because most of LDC investment project is irreversible or costly reversible and slow decision making. This implies that the policies leading macroeconomic determinate of budget deficit may not have immediate impact on budget deficit (Nur Hayait, 2012). The coefficient of rgdp and debt on the above regression result of insignificant, it may create reflections of ambiguity in different empirical finding in the area.

However we cannot claim that based on the above result of insignificant value indicating for avoidance of economic theory rather we can simply state that in the very short run period budget deficit don't much responsive to economic growth boosting, outbreak of inflations and deficit doesn't followed debt (Salman, 2003). The result is in line with the finding of several economists. (Anantha and Gayithri, 2012) is the typical cause where fiscal deficit compositions and economic growth relations in India: it concludes "the relationship between fiscal deficit and economic growth is one of highly debated issues in economic literatures". (Attiya et al., 2010) also arrive at similar conclusions based on multi countries panel data for testing the macroeconomic impacts of the budget deficit in EU member states using linear regressions with fixed effects models.

The significances of explanatory variables, on both regressions result of fixed effect LSDV and interaction variables of debt model. The value of broad money supply which is the total stock of the money circulating on the economy and measured in high powered money have statistically significant at $1 \%$ in both regression result with expected sign of positive effect on budget deficit as before in the sample countries. Broad money supply is increased by one percent budget deficit of countries is increased by on average $78.2487 \%$ in the regions. This implied that the past level of pumping broad money supply to the economy from the public sector was contributed to the positive magnitude affections of budget deficit. The relations of broad money supply growth and budget deficit acquired in prominent place of macroeconomic literature over time with the views of two traditional approaches to explain the link Monetarists hypothesis (MH) and the fiscal theory of price level (FTPL) including a dynamic general macroeconomic model with imperfect competitions of new Keynesian theory. This might hold in a cause when broad money supply which is all adjustment has been taken place by the public (Dornbusch and Fisher, 1994). As result followed by the government budget deficit. Monetization of money supply leads to increase budget deficit and macroeconomic instability in the economy. As (Albert, 2008) stated that high inflations in developing countries emerges a fiscal driven from monetary phenomena. This immediately occurs government went to finace trough large and persistent budget deficits. It put a pressure on the huge budget imbalance of the public sectors and weak real revenue tax collections from tax of fiscal policy (Dornbusch and Fisher, 1994). The result of this study is in line with the theoretical model predications of simple open Keynesian economic theory of budget deficit that we have dealt in methodology as well as consistence result of empirical investigations of (Poloz 1992; Manamba,2017 and Bose et al .,2007) and inconsistence with the empirical investigations of (Dwyer ,1982).

Total population growth is statistically significant and positively affect budget deficit at $1 \%$ level of significance. The significance of total population growth variables analysis on the regressions result implied that, a $1 \%$ increment of total population growth (an increase the number of people that reside in a country per annum measured in percent) holding other factors constant is resulted on average $322.8173 \%$ of budget deficit increment to the public sectors. This is the fact that demographic pressure can affect the fiscal positions too, ageing population growth would cause an increasing in government spending on the state poisons to fill full social needs and fast population growth would also put more pressure on the government spending funds on public for a merit good to the society of the regions. In addition to this a rapid population growth has a negative impact on economic growth and consequences by the positive impact on public deficit. It stated rate of population growth has degrading a natural resource which makes lowering of the fertility rate of productions and it asks money to adequate health care of natural resource which increase public spending in the regions. Not only this, this evidence is support in our arguments rate of population growth affect budget with positive magnitude is increasing of spending each child in both health and educations in developing countries (Richard and Robert, 1997). The study is confirmed with the empirical result of (Ratna and Sari Lestari, 2016) that identify the raising of population growth is full contributions in to budget deficit increment on the regions. But also the result is inconsistence finding of the study of (Eugenia, 2012).In most of the least developed countries due to the presence of higher dependency ratios and unproductiveness of the man power, populations growth does not have any positive contributions to the economic growth that why total population growth is significant and positive impact for the increments of budget deficit of the countries even if there is argumentative theory that the impact of population growth on the economy which is the debated issues between African elites.

The positive and significant persistent effect of total unemployment rate at $5 \%$ level in line with the work of (Andrew et al., 2013 and Eugenia, 2012). The result from the table: 4.1 reveal that the variable of unemployment rate: a one percent increase of unemployment rate would result on average $136.4508 \%$ increase of budget deficit in the region of the study. This finding is inconsistence with the theoretical predictions of Keynesianism that government expenditure cans positively influence economic growth by increasing government consumptions 
through increasing investment, employment and profitability (Eze and Nwambeke, 2015). This is the fact that in most developing countries the actor of the economy is government (Gaberiel and Mohamed, 2011). Especially during the time of political period politicians get for re-elected purpose run a huge budget deficit for creations of job, reducing unemployment and economic growth but not true in LDC. The significant relationship between budget deficit and unemployment is efforts of the public sector investing on the necessary social program issue of the countries to bearing economic growth and reducing unemployment.

Empirical study of USA, which is consistence to this study on its graphical depictions effect of $1 \%$ unemployment rate on federal deficit 1970 to 2009, resulted each $1 \%$ of excess unemployment rate is automatically added $\quad \$ 60 \quad$ billon to the dicits (https://dickatlee.com/unemployemnt/deficit). Policy maker of the region of the countries has believed that huge government expenditure makes a significant contributions ensuring that the countries gain macroeconomic stability in the area. This is from the most common objective of macroeconomic policy of government and in least developed world the presence of high dependency ratio and unemployed of the man power would leads to the public to expend more to security purpose (S.Bawa and I.S.Abdullah, no date). Finally the budget that raised by the public sector to reduce unemployment in LDC is diverted by the autocratic processes of the authoritarian and the government does not gain the revenues from the economy due to the existence of high unemployed laboure forces on the regions.

Based on the empirical literature that the coefficient of real gdp, inflations and debt to be significant and positive effect on budget deficit of the regions. However its appears insignificant and positive effect. Studies show that different result for different studies in the regions (Attiya ,2010) using four major Asian countries showed indicates a strong positive impact of high income, inflations and large budget deficit to gdp ratio are significantly associated with large budget deficit. While (Dissanayake, 2016) reveals that identifying the relations between budget deficit and selected macro economic variables resulted strong and significant relationship between debt and real GDP growth rate. Thus the insignificant coefficients of the study indicate that, perhaps the institutional governmental surrounding and the non economic sector may be a more important factor in determining the budget deficits in the region of the study. Thus our measure of this study is the variable that we think is highly correlated with the unobserved heterogeneity components of the model.

Besides of the above explanatory variables of the regions, this study is concerned, the area of interest the time invariant variables that is country dummy use as an explanatory variables. The justifications of including country dummy in the study is: Firstly the nature of panel fixed effect model capturing the time invariant variables that may having the significant effect on the explained variably and Secondly the study also design the budget deficit is vary across the country, degree of sensitivity to the individual countries including the magnitudes. To investigate this analysis this study use country dummy as explanatory variable using Ethiopia as categorical dummy variables which naturally dropped in the regressions result. Not only this why researcher are using dummy variable as part of the regressions variables because of the indicating absence or presence of categorical effect that may be expect shift the result of the regressions and it use as instrument of mutual exclusive categories sound economic descriptions of qualitative data to numeric explanations.

Table 4.1 column 2 regression result of this study out of the six sample countries of the regions three of them are significant these are Tanzania, Senegal and Cote Divore this indicate that the budget deficit of the region is significantly different among the countries. The economic sense of these significant country dummy result is, as comparing to Ethiopia on average the amount of budget deficit in Tanzania has more than by $272.6939 \%$ this is the fact that especially on the Tanzania economy from $2016 / 17$ to $2020 / 2021$, which is great economic reform is takes place i,e the government is implemented the national five year plan which aiming nurturing industrializations for economic transformations and human development in Tanzania under the project of constrictions of new railway which is covered around $2707 \mathrm{~km}$ under the three branch of project designs, Mkunazi Agricultural city, crude oil Pipeline(Hoima,Uganda to Tanga port in Tanzania collaborations with the Uganda government) and expansions of Dar es salaam Port including new international air ports in Dar es Salaam finally the government of Tanzania also plane to built phase II of Dar es Salaam Rapid Bus System (DART) (www.cblacp.eu). Due to these factors the budget balance of Tanzania face higher amount as comparing to Ethiopia by the $272.6939 \%$ at $1 \%$ significances level.

The positive sign and significance at $1 \%$ of the country dummy variables was Senegal with the base categorical group of Ethiopia. This means like on the above explanations of variables: as comparing to Ethiopia the amount of budget deficit of Senegal is more than on average by the $488.2095 \%$ in the regions. This implied that due to the reason higher oil price and stronger imports of capital good (www.worldbank.org.country.sengal). And also the persistent deficit of Senegal is wage increase to meet sticker demand in the public sector and increase of spending on the security have push a pressure of budget deficit widen in Senegal (www.imf.country.sengal). The crucial reason of the Senegal budget deficit is over load or showed higher amount on the categorical base group is from the year 2015 to 2019 World Bank has approved 122 projects for Senegal which is estimated totally about US\$ 3 billion with the collaborations of international development associations (IDA). The designed project 
operations is like to improving agriculture, rural development, infrastructure ,environmental protections, transportations ,populations / health / nutrition / public and private sector development and improving natural disaster management system as a general, for detail you can invite cited next(www.worldbank.org.country.project and Jonas et al., 2017). Due to these reason Senegal budget deficit has more than from Ethiopia on average by $488.2095 \%$ in the regions.

The categorical dummy variable of Cote Divore on the regression result, it showed that positive and significant at 1\% level in Table : 4.1columns 2.The economic sense of this regression result is that, the budget deficit of Cote Divore as comparing to Ethiopia categorical group is more than on average by the $312.121 \%$ on the region of this study. This indicating that due to the reason, from the year 2012-2015 the Cote Divore Government of national development planned implemented a new policy aimed at accelerating growth dynamic revolving around prudently selected power full growth engines on the basis of Republic of Cote Divore on the two major of economic growth driver. The First is "transversal" source of growths which cross all sectors and promote a growth fostering environment and the second is driver of growth is "vertical" axes of growth (Republic of Cote Divore Minster of Plan and Development ,2013) for detail invite cited next (UNDP Cote Devore,2012).

However the categorical dummy variable of Nigeria and Kenya showed insignificant result as comparing to base group of Ethiopia that doesn't explain the relation of budget deficit including the magnitudes on this country. This due to the source of economic revenue is different as comparing to the other especially Nigerian economy is highly dependent on crude oil revenue which is not for Ethiopia. These both national and international consumers of crude oil of the country create diplomatic relations to Nigerian which used as source of income to the public from remittance even though crude oil is dominating the federal government source of revenue; Agriculture also put on the lion share of Nigerian economy contribution which is estimated around $22 \%$ in 2018 as share of gdp (Joseph and Sule, 2016). The crude oil is not only contributing as source of revenue from national exchange rate but also it use part of tax revenue. IMF, (2017) reports from the year 1986 to 2015 it recorded both oil and non oil tax revenue contributed $75 \%$ to the Nigerian economy which estimated around $25 \%$ as share of GDP in the national income the negative magnitude is happened due to the above reasons as comparing to Ethiopia.

Coming to another insignificant country dummy variable with the categorical base group of Ethiopia, Kenya is the cause; Like Nigeria except the magnitude of the coefficient is insignificant because the source of the Kenyan economy is strong as comparing to Ethiopia (African development bank group, 2018). The most major sector of revenue in Kenya is local revenue, equitable share, conditional grant, loans and donor funding (USAID, DANIDA and DFID) these sector is advanced and technologies as comparing to Ethiopia which have a different significant nature data on budget of the countries resulted unrelated out put is happened at the end in regression result of this study (George, 2009).

The final mission of this estimation result of the study on the regions is showed on the above Table: 4.1 columns 3, was the issue of interaction variable of debt. The objective here was the use of interaction variable of logarithm of debt in the region was to know whether the source of debt is the same or not among the sample countries. Because alternative strategy for testing weather parameters differs across group, dummy variable and interactions terms (Richard, 2015). But this study concern only the parameter was different across group or not that is debt. However this approach has so limitations like it don't tell the coefficient of different across groups (ibid).The possible strategy of this study to capture the problems explained above is incorporating all dummy variables for group members with the other independent variables. The regression result of above table symbolized by "Iln-DEBTAR" on raw 14 and column 3 .This implied that the source of debt among the countries of the region is not the same. Because the econometrics estimations result is not significant on the model of this study. This is consistence with the empirical results of (Aliko, 2014).According to him the sources of African debt market are categorized in to three these are south, west and east Africa source of debt.

\section{Recommendations}

○ Reducing unemployment using the following techniques.

\# Educations and short term training to help reduce structural unemployment. Thus the economy aiming to give the long term unemployed new skill which enable them to find jobs in developing industries of the countries.

* Subsidy to encouragement firms to invest in the deepest area that boosting the Aggregate demand to aiming for positive economic growth that absorbed the unemployment rate on the economy of the regions as well as it also helps to reduce the concentrations of unemployment in one area. Not only this privileged treatment should be given for small and younger manufacturing firms that are supposed to be the remedial for the fastest growing member of unemployment like credit, service and exchange accesses.

* Accessing more flexible laboure markets to make it easier to hire and let off works. Though abolishing and make it easier to haired and let off worker may encourage more jobs creations. Reducing the power of the trade unions that would be the cause for the outbreak of real wage unemployment rate in the 
market which putt a burden on the public spending.

\# Cutting spending on pensions making the peoples to work longer which increase productivity as a result the public taxes collections base is widen from the income and VAT taxes which increase the government revenues and reduce public deficits in the regions.

- The policy maker should reduce the expansions of broad money supply through the executive and parliamentary of the countries play assigned role in the budgeting processes. Avoiding budgeting on the political issues that pushed budget deficit upward to the economy. The policy maker should consider the solid constraint of the government to achieve the optimality of the economic growth.

* Restricting public borrowing the money from central bank including the higher authoritarians'. It should be better mobilizing of resources from the citizen of the countries.

* A creation of money designed by the policy maker is according to the prevailing economic situations of the countries and don't directed by the government.

- Another policy implications of the study is how to interrelated population growth and budget deficit;

* The fed was better to doing the common attributions of both populations' growth and technological progress. It should designing policy of engaging the productive force in to income generating works that use as input development of technological progress and collect the amount of revenue which should be for government wisely.

* Giving short term training to Devlop co-operative and teamwork to calling additional innovative group ideas and adoption of new technology the paw of the way for economic growth which is boosting full employment rate increasing public revenue from income tax or VAT.

* Creating awareness of the peoples regarding to coming of one more new child relating to income. Making award about saving and establishing easily available finical sectors to accesses the society that promote investment contributing positive impact on the economic growth.

\section{Reference}

Adriana Kugler, (2005). Employment Consequences of Restrictive Permanent Contracts Evidence from Spanish Labor Market Reforms*.

African development bank Group, (2018). East African Economic outlooks.

Albert Makochekanwa, (2008). The impact of a budget deficit on inflation in Zimbabwe.

Ali Salman Saleh, (2003). The budget deficit and economic performance a survey.

Aliko Dangote, (2014). The African debt market (the world economic forum in Davos).

Anantha Ramu, M. R., and K. Gayithri, (2012). Fiscal deficits decomposition and economic growth relations in India: a time series econometrics analysis.

Anyanwu J.C. (2016). Empirical Analysis of the Main Drivers of Income Inequality in Southern Africa. Annals of economics and finance.

Asefa Tefera, (2015). Budgeting System in Ethiopia: Program Budget System.

Attiya Y., Javid, Umaima Arif and Asma Arif1, (2010). Economic, Political and Institutional Determinants of Budget Deficits Volatility in Selected Asian Countries.

Baltagi, B., S. Song, B.J ung, and W. Koh., (2007). Testing for serial correlations, spatial autocorrelations and random effects using panel data. Journal of Econometrics 140:5 \{51\}.

Bose, N. Haque M.E. \& Osborn, D.R., (2007).Public Expenditure and Economic Growth: A Disaggregated Analysis for Developing Countries. The Manchester School.

Brüderl J., (2015). Applied Panel Data Analysis Using Stata.

Christian Ebeke Mansour, Gregoire-Grazionsi (2016). "The power of tax in sub- Saharan Africa LUTs, VATs and SARAs".

Croissant Y. and Millo G., (2008). Panel Data Econometrics in R: The plm Package.

D.M.S.B. Dissanayake (2016). "Identifying the Relationships between Budget Deficit and Selected Macroeconomic Variables".

Dornbusch and Fisher S., (1994). Macroeconomics. Massachusetts Institute of Technology, $6^{\text {th }}$ Editions, USA: McGraw-Hill.

Dwyer, Gerald P., (1982). Inflation and Government Deficits. Economic Inquiry, Vol. XX, pp.315-329.

Economic Commissions of African report, (2007).

Economic Report of African report, (2010).

Economic commission of Africa, (2011).

Economic Commission for Africa, (2017). Urbanization and Industrialization for Africa's Transformation.

Eugenia-Ramona Mara, (2012). Determinants of fiscal budget volatility in old versus new EU member states.

Fareeha Safdar and Ihtsham Ul Haq Padda, (2017). Impact of Institutions on Budget Deficit the Case of Pakistan.

Gaberiel Baffour Awuah and Mohamed Amal, (2011). Impact of globalizations the ability of less developed countries (LDCs) firms to cope with opportunity and challenges European Business reviews. Vol.23. 
George Kipng'etich Kosimbei, (2009). Budget Deficits and Macroeconomic Performance In Kenya: An Empirical Analysis.

Genius Murwirapachena, Andrew Mareda and IreenChoga and (2013). The economic Determinant of Budget deficit in South Africa.

Gongera Enock George*, Robert Mindila*, Simion Nyakwara*and Barrack O.Ouma*(2013). An Evaluation of Economic Strategies in Budget Deficit Reduction in Kenya.

Greene, W.H., (2003). Econometric Analysis Prentice Hall, New York, Fifth edition.

Hobbes, T. (1951) “The Cambridge Companion to Hobbes's Leviathan”. Free University of Bolzano, Italy.

Hun Myoung Park, (2011). Practical guide to panel data model: a step by step analysis using Stata.

Irma Adelman, (1999)" Role of government in economic development".

IMF staff position notes, (2010). Long-Term Trends in Public Finances in the G-7 Economies.

James Gwartney et al., (1998). The Size and Functions of Government and Economic Growth.

Jonas Soderlud, Shankar and Christopher Biesenthal, (2017). The past and present mega project Of Senegal.

Joseph Okwori and Abubakar Sule, (2016). Revenue source and economic growth in Nigeria.

Judson R.A. And Owen A.L, (2006). Estimating Dynamic Panel Data Models: A Practical Guide for Macroeconomists.

Keynes, J. M. (1936). The General Th Keynes, J. M. (1936) “The General Theory of Employment, Interest, and Money”. New York. Theory of Employment, Interest, and Money.

Kuútepeli, Y., (2005). The Relationship between Government Size and Economic Growth: Evidence from a Panel Data Analysis; Dokuz Eylül University.

Manamba Epaphra (2017) Analysis of budget deficits and macroeconomic fundamentals: A VAR- VECM approach.

Mankiw, G. (2007). Macroeconomics, $7^{\text {th }}$ editions. Worthy publisher.

Mika Tujula and Guido Wolswijk, (2004).What Determines Fiscal Balances? An Empirical Investigation in determinants of changes In OECD Budget Balances.

Morra Winnyrose, (2014). The relation of between budget deficit financing and economic Growth in Kenya.

Musgrave, R. (1959). Theory of Fiscal Policy. New York: McGraw Hill.

Natalia SKOROBGTOVA, (2016). Macroeconomic instability: its cause and consequence for the Economy of Ukraine.

Nur Hayait Abd Rahman, (2012): The relation between budget deficit and economic growth from Malaysian Prospective: ADL approach.

Pigou, A. C., (1912) .Wealth and Welfare. London: Macmillan.

Poloz, S.S., (1992). Fiscal policy and external balance in the G-7 countries. Bank of Canada, Technical Report Number 60.

Ratna Anggraini ZR and Sari Lestari Zaninal Ridho, (2016). Health budget, human capital and Population growth: empirical study in Indonesia.

Republic of Côte d'Ivoire minster of plan and development, (2013). National development plan 2012-2015. Washington.D.C: international Monterey fund.

Richard Williams, (2015). Interaction effect and group compressions.

Ricardo, D., (1817) .On the Principles of Political Economy and Taxation. Rod Hay's Archive For the History of Economic Thought, McMaster University, Canada.

Richard P. Cincotta and Robert Engelman, (1997). Economic and rapid change: the influence of Population Growth.

Robert Suphian1, (2017). Trade Balance Determinants in East African Countries.

Salman Saleh, (2003).The budget deficit and economic performance, survey faculty of business working paper university of Wollongong.

S.Bawa and I.S.Abduahi, Threshold effect of inflations on economic growth in Nigeria, Central Bank Nigeria Journal of Applied Statistics 3(1), no date.

Smith, A., (1776). An Inquiry into the Nature and Causes of the Wealth of Nations.R. H. Campbell and A. S. Skinner, eds. Liberty Fund: Indian opolis.

Tasew Tadesse, (2011). Foreign aid and Economic growth in Ethiopia. MPRA paper 33953, university of library of Munich, revised spe20 2011.

United nation development program Cote Divore, (2012). 
Appendixes I: Result of test parm.

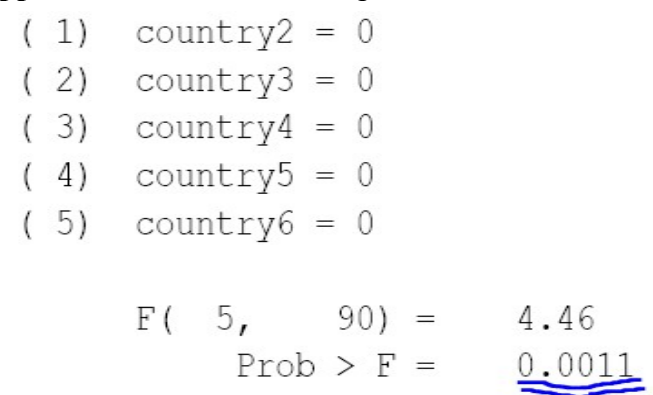

Source: Own competitions Based on Available Data (Stata SE/14.O)

Appendixes II: The Fixed Effect Model Regressions when Time invariant variables are Controlled by the Model.

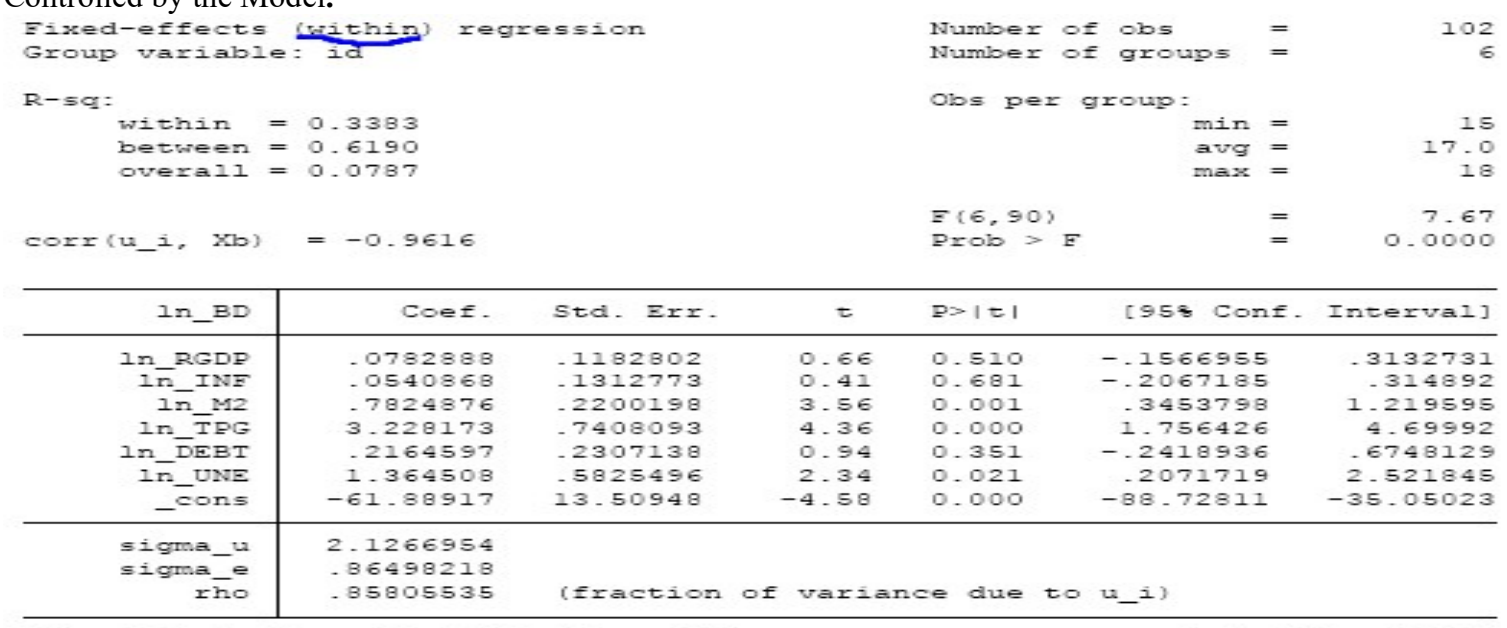

F test that all uni=0: F(5, 90) $=4.46$

Source: Own competitions Based on Available Data (Stata SE/I4.O)

Appendixes III: Result of least square dummy variables (LSDV).

i.counrytyname _Icounrytyn_1-6 (naturally coded; _Icounrytyn_1 omitted)

\begin{tabular}{|c|c|c|c|c|c|c|}
\hline Source & ss & df & MS & Number of obs & $=$ & 102 \\
\hline Model & 37.2882665 & 11 & 3.38984241 & Prab $>F$ & $=$ & 0.0000 \\
\hline Residual & 67.3374759 & 90 & .748194176 & R-squared & $=$ & 0.3564 \\
\hline Total & 104.625742 & 101 & 1.03589844 & Root MSE & $=$ & .8649 \\
\hline
\end{tabular}

\begin{tabular}{|c|c|c|c|c|c|c|}
\hline In_BD & Coef. & Std. Err. & $t$ & $\mathrm{P}>|\mathrm{t}|$ & [95\% conf. & Interval] \\
\hline In $\mathrm{RGDP}$ & .0782888 & .1182802 & 0.66 & 0.510 & -.1566955 & .3132731 \\
\hline ln_ INE & .0540868 & .1312773 & 0.41 & 0.681 & -.2067185 & .314892 \\
\hline ln & .7824876 & .2200198 & 3.56 & 0.001 & .3453798 & 1.219595 \\
\hline In_ $\bar{T} P G$ & 3.228173 & .7408093 & 4.36 & 0.000 & 1.756426 & 4.69992 \\
\hline In $\overline{\mathrm{DEBT}}$ & .2164597 & .2307138 & 0.94 & 0.351 & -.2418936 & .6748129 \\
\hline In_ UNE & 1.364508 & .5825496 & 2.34 & 0.021 & .2071719 & 2.521845 \\
\hline Icounrytyn_2 & .8509877 & .7956755 & 1.07 & 0.288 & -.7297606 & 2.431736 \\
\hline Icounrytyn 3 & 2.726939 & .7245052 & 3.76 & 0.000 & 1.287583 & 4.166295 \\
\hline Icounrytyn_4 & -.7239443 & .660294 & -1.10 & 0.276 & -2.035734 & .5878449 \\
\hline Icounrytyn 5 & 4.882095 & 1.530029 & 3.19 & 0.002 & 1.842426 & 7.921765 \\
\hline Icounrytyn_6 & 3.121084 & 1.154449 & 2.70 & 0.008 & .8275692 & 5.414599 \\
\hline _cons & -63.66547 & 14.04508 & -4.53 & 0.000 & -91.56848 & -35.76247 \\
\hline
\end{tabular}

Source: Own comperitions Based on Available Data (Stata SE/I4.O) 
Appendixes VIII: Regression Results of Fixed Effect Model with the interaction variables

\section{Of debt.}

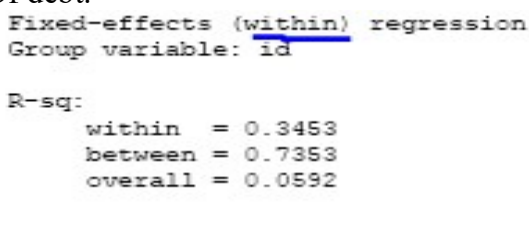

92

corrtu_i, Xo) $=-0.9833$

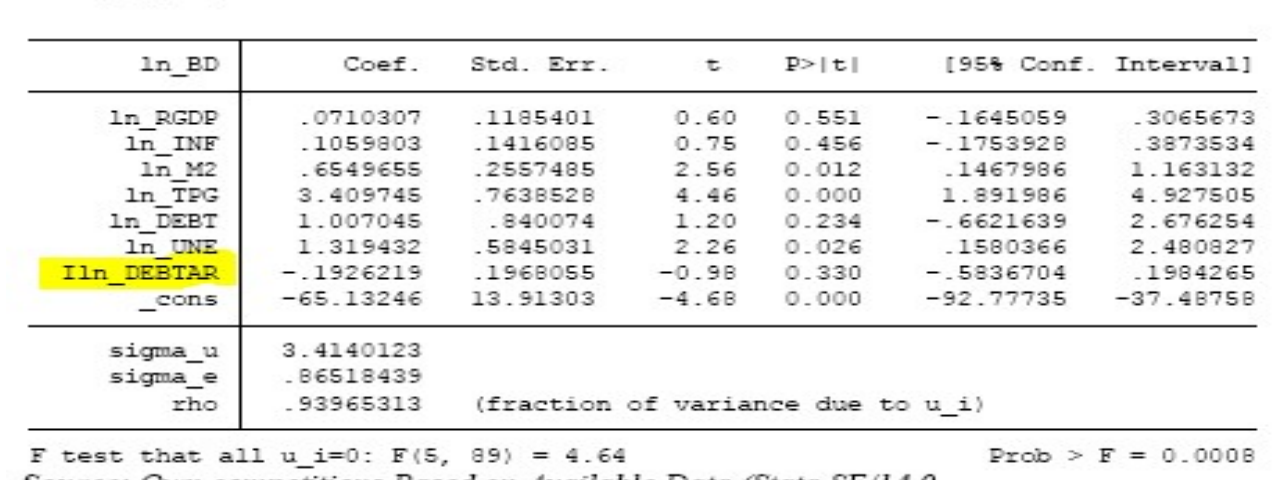

$F$ test that all u_i=0: $\mathrm{F}\langle 5,89\rangle=4.64$

Source: Own competitions Based on Available Data (Stata SE/14.O

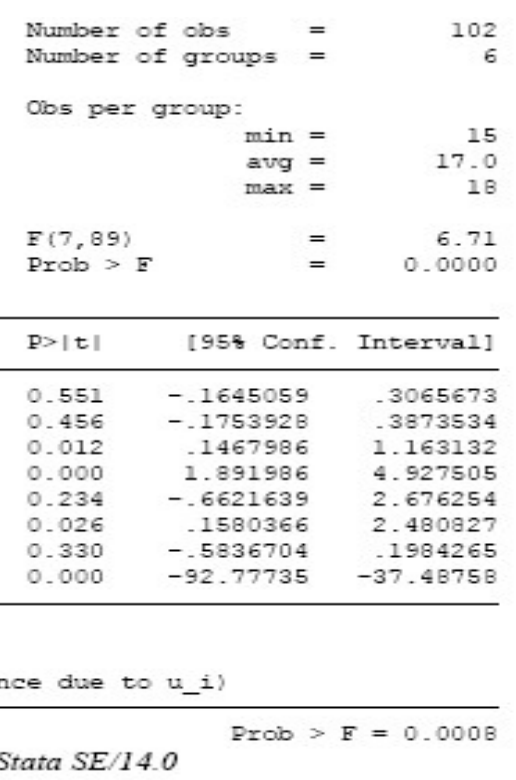

